\title{
Chronic Kidney Disease and Multiple Myeloma Case in Clinical Nephrology
}

\author{
Ahmet Karataş ${ }^{1}$, Burcu Ülküden², Mervegül Kaya ${ }^{3}$, Aykut Özturan ${ }^{4}$ \\ ${ }^{1}$ Ordu University Faculty of Medicine, Division of Nephrology Department of Internal Medicine, Ordu, Turkey \\ ${ }^{2}$ Ministry of Health Ordu University Faculty of Medicine Education and Research Hospital Hematology, Ordu ,Turkey \\ ${ }^{3}$ Ordu University Faculty of Medicine, Family Medicine Research Assistant, Ordu,Turkey \\ ${ }^{4}$ Ordu State Hospital Internal Medicine, Ordu,Turkey
}

Received: 06 March 2020, Accepted: 13 April 2020, Published online: 30 April 2020

(C) Ordu University Institute of Health Sciences, Turkey, 2020

\begin{abstract}
Multiple myeloma (MM) is a neoplastic plasma cell dyscrasia identify by anemia, recurrent infections, increased serum and / or monoclonal protein in urine, osteolytic bone lesions, hypercalcemia and renal failure. MM accounts for approximately $1 \%$ of all cancer cases and $10 \%$ of hematological malignancies MM related renal failure is an important prognostic factor leading to early mortality and ranges from 20-50\% depending on the frequency of kidney disease in MM. In the present paper, we report that advanced age, concomitant chronic renal failure with unknown cause and anemia should always bring MM to mind; In these cases, serum and urine immunization electrophoresis should be requested even if serum protein electrophoresis is normal.
\end{abstract}

Key words: Light chain; The immunofixation; multiple myeloma

Suggested Citation: Karatas A, Ulkuden B, Kaya M, Ozturan A. Chronic Kidney Disease and Multiple Myeloma Case in Clinical Nephrology. Middle Black Sea Journal of Health Science, 2020; 6(1):135-138.

\section{Address for correspondence/reprints:}

Aykut Özturan

Telephone number: +90 (452) 2343232

ORCID-ID 0000-0002-4645-5225

E-mail: draykutt@gmail.com

DOI: $10.19127 / \mathrm{mbsjohs.694541}$

\section{Introduction}

Multiple myeloma (MM) accounts for approximately $1 \%$ of all cancer cases and $10 \%$ of hematological malignancies (Rajkumar et al.,2014). Each year over 32,000 new cases are diagnosed in the United States, and almost 13,000 patients die of the disease (Siegel et al.,2020). The annual age-adjusted incidence in the United States has remained stable for decades at approximately 4 per 100,000 (Kyle et al.,2004). MM is more common in males (approximately 1.4 / 1), with an average age of 69 for males and 72 for females at the time of diagnosis (Barlogie et al., 2006). Multiple myeloma can be presented with three different clinical pictures: typical pattern, light chain myeloma and nonsecretory myeloma. The classic findings leading to diagnosis are bone pain, hypercalcemia, sedimentation height, anemia, and lytic bone lesions (Kyle et al., 2003). Bone pain is generally felt in the 
back and chest wall, less often in the extremities. In $80 \%$ of patients, lytic bone lesions, osteopenia, osteoporosis, or pathological fractures can be detected in skeletal surveys (Kyle et al., 2003). Unlike other malignancies that metastasize to bone, the osteolytic bone lesions in multiple myeloma exhibit no new bone formation (Roodman ,2009). Bone disease is the main cause of morbidity and can be best detected using low-dose whole body computed tomography (WB-CT), fluoro-deoxyglucose (FDG) positron emission tomography/computed tomographic scans (PET/CT), or magnetic resonance imaging (MRI) (Hillengass et al., 2019) Sedimentation has increased significantly and may be over $100 \mathrm{~mm} / \mathrm{h}$. ( Alexandrakis et al., 2003) Anemia is generally normochromic normocytic and is seen at the time of diagnosis in $73 \%$ of patients and throughout the disease in 97\% (Kyle et al., 2003). Renal involvement rate is $48 \%$ and it is more common in light chain myeloma (Winearls, 1995).

Renal involvement in MM was first described in 1845 by Henry Bence Jones detecting oxidized albumin in the urine of a myeloma patient, which would later be called Bence Jones protein (Jones, 1848). MM-related kidney failure (ESRD) is an important prognostic factor causing early mortality. The frequency of renal failure in MM varies between 20-50\% depending on the definition (Alexanian et al., 1990; Eleutherakis-Papaiakovou et al., 2007). Renal failure despite being generally moderate (between stage 2 and stage 4 ), $10 \%$ of patients still require renal replacement therapy (Torra et al., 1995). MM damage is mainly caused by the effect of monoclonal light chains. Hypercalcemia although less frequently is another cause of kidney failure (Blade and Rosinol, 2005). Dehydration, hyperuricemia, nephrotoxic drugs, and use of contrast agents are other factors that are effective in the development of kidney failure and they cause kidney damage by increasing the effects of light chains rather than being the main cause of kidney failure (Alexanian et al., 1990; Kyle et al., 2003). It is known that with the improvement of kidney failure, negative effects on survival disappear. Therefore, it is important to identify the factors that affect the healing of kidney failure. Alongside supportive therapy such as appropriate fluid replacement, correction of hypercalcemia and avoiding nephrotoxic agents, chemotherapy for MM should be initiated quickly. With the treatment, the rate of recovery of kidney failure reaches $25-58 \%$ (Blade and Rosinol, 2005; Eleutherakis-Papaiakovou et al., 2007). In the present paper, we report that advanced age, concomitant chronic renal failure with unknown cause and anemia should always bring MM to mind; In these cases, serum and urine immunization electrophoresis should be requested even if serum protein electrophoresis is normal.

\section{Case}

An 82-year-old male patient has been followed up in the nephrology outpatient clinic for nine months due to chronic kidney damage (CKD). Five months prior, in addition to anemia, the patient with a marked sedimentation height was referred to the hematology outpatient clinic. CKD and hypertension have been present for 9 months in patient history. The medications patient was administrated were polystyrene sulfonate calcium salt, sodium bicarbonate, iron II, darbopoetin alpha. The patient did not consume alcohol or smoked.

In the physical examination of a middle aged male patient with no acute ailments, decreased skin turgor, dry tongue, pale skin was found and a fever of $37^{\circ} \mathrm{C}$, blood pressure of $140 / 80 \mathrm{mmHg}, 96 / \mathrm{min}$ pulse and respiratory rate of 18 per minute is recorded. Respiratory sounds were normal in auscultation. Cardiac sounds were normal during the cardiac examination. Abdominal examination revealed no distention, tenderness, and organomegaly. Intestinal sounds were normal. There was no costovertebral angle sensitivity. No edema was detected in both lower extremities. No lymphadenopathy was detected in the cervical, axillary and inguinal regions. No feature present in neurological examination. Other system examinations were normal.

In Hemogram WBC $11430 \mathrm{uL}, \mathrm{Hb} 10.5 \mathrm{gr} / \mathrm{dl}$, Hct $33.2 \%$, MCV 91.7 fl, RBC $3.6210^{\wedge} 6 / \mathrm{uL}$, Neu $6410 \mathrm{uL}$, Monocyte $620 \mathrm{uL}$, Lymphocyte $3560 \mathrm{uL}$, PLT 193.000 UL.

Routine biochemistry Glucose $86 \mathrm{mg} / \mathrm{dL}$ urea $49.2 \mathrm{mg} / \mathrm{dl}$, creatinine $1.58 \mathrm{mg} / \mathrm{dl}$, sodium $140 \mathrm{mEq}$ /L, potassium $6.13 \mathrm{mEq} / \mathrm{L}$, calcium $9.6 \mathrm{mg} / \mathrm{dl}$, chlorine $104 \mathrm{mEq} / \mathrm{L}$, phosphorus $3.4 \mathrm{mg} / \mathrm{dl}$, uric acid $5.5 \mathrm{mg} / \mathrm{dl}$, AST $21 \mathrm{U} / \mathrm{L}$, ALT $13 \mathrm{U} / \mathrm{L}$, Total protein $8.4 \mathrm{~g} / \mathrm{dl}$, albumin $4.1 \mathrm{~g} / \mathrm{dl}$, CK $107 \mathrm{U} / \mathrm{L}$, sedimentation $105 \mathrm{~mm} / \mathrm{h}, \mathrm{CRP}$ was $1.3 \mathrm{mg} / \mathrm{L}, \mathrm{LDH}$ 189 UL. Iron $100.8 \mathrm{ug} / \mathrm{dL}$, TDBK $230.8 \mathrm{ug} / \mathrm{dL}$, ferritin $860.7 \mathrm{ng} / \mathrm{mL}$, folate $2.85 \mathrm{ng} / \mathrm{mL}$, vitamin B12 $357.7 \mathrm{pg} / \mathrm{mL}$, reticulocyte count $1.17 \mathrm{ng} / \mathrm{mL}$, Parathormone $70.91 \mathrm{ng} / \mathrm{mL}, 25-\mathrm{OH}$ D $16.81 \mathrm{ng}$ was / mL. PT was $16.9 \mathrm{sec}$, aPTT $40.7 \mathrm{ng} / \mathrm{mL}$, INR 1.22 $\mathrm{ng} / \mathrm{mL}$. 
Complete urine examination and sediment Density 1013, pH 5, leukocyte negative, erythrocyte negative, protein +1 , glucose negative, nitrite negative, urobilinogen negative, ketone negative.

Venous blood gas $\mathrm{pH} 7.28, \mathrm{HCO} 3$ 18.6, $\mathrm{PCO} 2$ 39.8, PO2 32.3

In advanced examination and examination of hematology outpatient clinic Serum beta-2 microglobulin is found as $6.51 \mathrm{mg} / \mathrm{L}$.

\section{Immunization}

electrophoresis-serum quantitative monoclonal protein was $\mathrm{Ig}$ A $908 \mathrm{mg} /$ dL, IgG 1724 mg / dL, IgM 56.5 mg / dL, Kappa light chain was $4.16 \mathrm{~g} / \mathrm{L}$, Lambda light chain was $3.31 \mathrm{~g}$ / L. Hemoglobin electrophoresis was; HbA 97.4\%, HbA2 2.57\% HbF 0\%. ARB (-) in sputum, Sputum culture: no reproduction.

\section{Discussion}

Multiple myeloma is malignant proliferation of advanced plasma cells; seen in elderly, often presenting with renal failure and hypercalcemia. As with many types of malignancies, the benefit of early diagnosis is indisputable, and further evaluations are often required aside a presence of high clinical suspicion. Clinical and laboratory findings in light chain myeloma often resemble typical MM.

The revised International Myeloma Working Group criteria for the diagnosis of multiple myeloma requires the presence of one or more myeloma defining events (MDE) in addition to evidence of either $10 \%$ or more clonal plasma cells on bone marrow examination or a biopsy-proven plasmacytoma. MDE consists of established CRAB (hypercalcemia, renal failure, anemia, or lytic bone lesions) features as well as 3 specific biomarkers: clonal bone marrow plasma cells $\geq 60 \%$, serum free light chain (FLC) ratio $\geq 100$ (provided involved FLC level is $\geq 100 \mathrm{mg} / \mathrm{L}$ ), and more than one focal lesion on MRI. (Rajkumar, 2020)

Serum protein electrophoresis alone is insufficient in MM. In the presence of a typical pattern MM, M protein can be detected by serum protein electrophoresis at a rate of $82 \%$, which increases to $97 \%$ if serum and urine immunofaction electrophoresis is added (Kyle et al., 2003).

In $20 \%$ of all MM cases, only light chain is present in serum and urine, and in this table, also called light chain myeloma, one third of patients are presented with renal failure. In light chain myeloma, serum or urine kappa and lambda type light chains can be detected by serum and urine immunofaction electrophoresis.

\section{Conclusion}

Advanced age concomitant chronic renal failure with unknown cause and anemia should always bring MM to mind; In these cases, serum and urine immunization electrophoresis should be requested even if serum protein electrophoresis is normal.

Patient Approval: Approval was received for this study from the patient.

Peer-review: Externally peer-reviewed.

Author Contributions: Concept- A.K.; Design-A.K, AO.; Materials- A.K, BU, MK; Data Collection and/or Processing- A.K, BU, MK.; Literature Review- A.K, BU, MK, AO; Writing- A.K, A.O; Critical Review- A.K, BU, MK, AO

Conflict of Interest: No conflict of interest was declared by the authors.

Financial Disclosure: The authors declared that this study hasn't received no financial support.

\section{References}

Alexandrakis MG, Passam FH, Ganotakis ES, Sfiridaki K, Xilouri I, Perisinakis K, et al. The clinical and prognostic significance of erythrocyte sedimentation rate (ESR), serum interleukin-6 (IL-6) and acute phase protein levels in multiple myeloma. Clin Lab Haematol 2003; 25 (1): 41-6.

Alexanian R, Barlogie B, Dixon D. Renal failure in multiple myeloma. Pathogenesis and prognostic implications. Arch Intern Med 1990; 150 (8): 1693-5.

Barlogie B, Shaughnessy J, Epstein J, et al. Williams Hematology. 7th ed. USA: Mc Graw Hill Companies; 2006

Blade J, Rosinol L. Renal, hematologic and infectious complications in multiple myeloma. Best Pract Res Clin Haematol 2005; 18 (4): 635-52.

Eleutherakis-Papaiakovou V, Bamias A, Gika D, et al. Renal failure in multiple myeloma: incidence, correlations, and prognostic significance. Leuk Lymphoma 2007; 48 (2): 337-41.

Hillengass J, Usmani S, Rajkumar SV, et al. International myeloma working group consensus recommendations on imaging in monoclonal plasma cell disorders. Lancet Oncol 2019;20:e302-e12

Jones HB. On a new substance occuring in the urine of a patient with mollities ossium. Philos Trans $\mathrm{R}$ Soc Lon 1848; 138: 55-62

Kyle RA, Gertz MA, Witzig TE, Lust JA, Lacy MQ, Dispenzieri A, et al. Review of 1027 patients with newly diagnosed multiple myeloma. Mayo Clin Proc 2003; 78 (1): 21- 33 
Kyle RA, Therneau TM, Rajkumar SV, Larson DR, Plevak MF, Melton LJ, 3rd. Incidence of multiple myeloma in Olmsted County, Minnesota: Trend over 6 decades. Cancer 2004;101:2667-74.

Rajkumar SV, Dimopoulos MA, Palumbo A, et al. International Myeloma Working Group Updated Criteria for the Diagnosis of Multiple Myeloma. Lancet Oncol 2014;15:e538-48.

Rajkumar SV. Multiple Myeloma: 2020 update on Diagnosis, Risk-stratification, and Management. Am J Hematol. 2020 Mar 24. doi: 10.1002/ajh.25791

Roodman GD. Pathogenesis of myeloma bone disease. Leukemia 2009;23:435-41

Siegel RL, Miller KD, Jemal A. Cancer statistics, 2020. CA Cancer J Clin 2020;70:7-30

Torra R, Blade J, Cases A, et al. Patients with multiple myeloma requiring long-term dialysis: presenting features, response to therapy, and outcome in a series of 20 cases. Br J Haematol 1995; 91 (4): 854-9.

Winearls CG. Acute myeloma kidney. Kidney Int 1995; 48 (4): 1347-61. 